\title{
SPRAY NOZZLES PERFORMANCE IN FUNGICIDES APPLICATIONS FOR ASIAN SOYBEAN RUST CONTROL
}

Doi:http://dx.doi.org/10.1590/1809-4430-Eng.Agric.v37n4p709-716/2017

\section{CLÉBER FRANÇA DURÃO ${ }^{1 *}$, WALTER BOLLER ${ }^{2}$}

${ }^{1 *}$ Corresponding author. Postgraduate Program in Agronomy. University of Passo Fundo / Passo Fundo - RS, Brazil. E-mail: cfd.rs@hotmail.com

\begin{abstract}
The performance of fungicides in controlling Asian soybean rust depends, in part, the spray quality of these products. The market of components to spray offers new types of nozzles which generate droplets with different characteristics. This study aimed to verify whether applications of fungicides with different spray nozzles interfere in soybean rust control. The experiment was conducted in the 2013/2014 harvest. The experimental design was a randomized block with three replications, and compared ten spray nozzles and a control without fungicide application. The applications were made with a backpack sprayer pressurized with $\mathrm{CO}_{2}$, set to apply a spray volume of $150 \mathrm{~L} \mathrm{ha}^{-1}$. For the determination of severity four plants per plot were sampled, quantifying in each leaflet the number of uredinia $\mathrm{cm}^{-2}$, which permitted to integrate the area under the disease progress curve (AUDPC). We concluded that HYPRO GUARDIAN ${ }^{\circledR} 120015$ Single pre orifice flat spray nozzle, that generates medium size of droplets, provided the lowest AUDPC of soybean rust, as well as the use of fungicide reflected in grain yield, which was on average $288 \%$ higher than that obtained by the control without fungicide application.
\end{abstract}

KEYWORDS: Glycine max, Phakopsora pachyrhizi, chemical control, application technology.

\section{INTRODUCTION}

The soybean (Glycine $\max$ (L.) Merrill) is worldwide characterized as a crop of great economic importance. It is one of the main raw materials for food, being an important component of animal feed, soy bran and flour, because it is an excellent source of protein, and more recently it is used for industrial products and the production of biofuel (Souza, 2013).

Brazil is the $2^{\text {nd }}$ largest producer in the world with estimated production of approximately 102.459.1 million tons of grain produced in 33.189.00 million hectares cultivated in the 2015/2016 harvest (CONAB, 2013).

The great expansion of the cultivated area in the world has increased the number and severity of diseases that affect soybean, and more than 100 species of pathogens have been reported, of which 35 are of great economic importance (Beledelli et al., 2012).

In the 2000/2001 harvest, a new disease was identified in Brazil in the state of Paraná, the Asian soybean rust caused by the Phakopsora pachyrhizi Sydow \& Sydow fungus, which spread rapidly to other Brazilian states (Cunha et al., 2014).

It is important to detect the presence of Asian soybean rust in plants as soon as possible to obtain satisfactory disease control because the pathogen progresses rapidly (Dorrance et al., 2011). Therefore, it is necessary to carry out the chemical control of rust through the use of fungicides, which normally require several applications to protect plants against disease and to contribute to higher productivity, since ineffective control implies damages to production.

In the application of fungicide, aspects of the environment, highlighting the temperature, relative humidity, wind speed, the presence of dew and the occurrence of rainfall soon after the applications, should be associated with the application technology (Boller et al., 2011). Associated to this, for the success of application and control of the disease, the volume of fungicide and operational parameters must be observed (Constantin et al., 2012).

\footnotetext{
${ }^{2}$ Postgraduate Program in Agronomy - University of Passo Fundo / Passo Fundo - RS, Brazil. 
The lack of soybean cultivars resistant to Asian rust has been a challenge for the research, due to the great variability of the pathogen (Neves \& Blum, 2013). According to Weirich et al. (2013), genetic resistance is the most effective and economical way to avoid damages caused by disease in crop plants.

So the use of fungicide becomes an efficient alternative for the control of the disease (Godoy et al., 2012). This may be one of the reasons for the constant growth of soybean fungicide use in Brazil. In this context, the application technology is fundamental so that the droplet deposition shows uniformity over the target of interest. For this, the correct choice of the spray nozzle to be used is one of the most important factors to obtain an efficient application.

The market of spray components offers new spray nozzle models every year, which generate droplets with different characteristics. Thus, in order to control soybean rust, it is essential that the spray nozzle is capable of providing homogeneous droplet coverage, allowing the pulverized product to reach the lower third of the canopy of the crop (Nascimento et al., 2013).

Considering that from the closure of the canopy along the development of soybean cultivation, there is an increasing difficulty for the deposition of fungicide spray droplets on the middle and lower parts of the canopy, which makes it difficult to control the Asian rust. The hypothesis of this study is that there are spray nozzles capable of providing different efficacy to control this disease.

The aim of this study was to verify if applications of fungicides with different spray nozzles interfere in the control of soybean rust.

\section{MATERIAL AND METHODS}

The experiment was conducted at field level from January to May 2014 at the Experimental Station of the Seeds Company - Agricultural Research and Planning, located in the municipality of Água Santa - RS, with the following geographical coordinates: Latitude S $28^{\circ} 10^{\prime}$, Longitude W $52^{\circ}$ 02 'and altitude of $650 \mathrm{~m}$ above sea level. The site is located in the physiographic region of the Middle Plateau of Rio Grande do Sul State, Brazil, and is characterized by humid subtropical climate (Cfa) with soil classified as Humid Dystrophic Red Latosol (Streck et al., 2008).

The choice of soybean cultivar was according to the technical indication for South America, using the "BRASMAX ATIVA" cultivar (Super Early Cycle) and determined growth habit.

The sowing was carried out under no-tillage system, under wheat residues on 01/06/2013, at an average depth of $0.05 \mathrm{~m}$, using the spacing of $0.45 \mathrm{~m}$ between rows, density of 18 seeds per meter and final stand of 377.000 soybean plants ha ${ }^{-1}$. The fertilization was done with $250 \mathrm{~kg} \mathrm{ha}^{-1}$ of fertilizer of the $\mathrm{N}-\mathrm{P}_{2} \mathrm{O}_{5}-\mathrm{K}_{2} \mathrm{O}$ 04-30-10 formula, plus $120 \mathrm{~kg} \mathrm{ha}^{-1}$ of potassium chloride $(\mathrm{KCl})$, applied to V5 stage - fifth node, fourth trefoil.

The experimental design was in randomized blocks with three replicates. In the evaluation of fungicide performance and efficacy in the control of soybean rust, ten spray nozzles (Table 1) were considered by comparing disease severity and productivity between the treated and untreated (control) plots that did not receive any fungicide application.

The experimental units were composed of five cultivation lines, spaced by $0.45 \mathrm{~m}$ and with a length of $5.0 \mathrm{~m}$, making a useful area of $11.25 \mathrm{~m}^{2}$, being eleven plots per block, totaling 33 plots. 
TABLE 1. Composition of treatments, spray nozzles models, droplets characteristics and volumetric median diameter of the generated droplets.

\begin{tabular}{lccc}
\hline \multicolumn{1}{c}{ Nozzle model } & Nozzle type & Spray Quality* & VMD** \\
\hline JactoJA-2 & Hollow cone spray & Fine & $106-235 \mu \mathrm{m}$ \\
Micron110 DB 1.5 & Twin flat spray & Very fine & $61-105 \mu \mathrm{m}$ \\
Teejet DGTJ- 60 110015 & Twin pre-orifice flat spray & Fine & $106-235 \mu \mathrm{m}$ \\
Teejet XR110015 & Single flat spray & Fine & $106-235 \mu \mathrm{m}$ \\
Magno 110015-BD & Single pre-orifice flat spray & Fine & $106-235 \mu \mathrm{m}$ \\
Teejet TT 110015 & Single turbulence chamber flat spray & Medium & $236-340 \mu \mathrm{m}$ \\
Hypro GUARDIAN 120015 & Single pre orifice flat spray & Medium & $236-340 \mu \mathrm{m}$ \\
Agrotop AIRMIX 110015 & Air induction single flat spray & Medium & $236-340 \mu \mathrm{m}$ \\
$\begin{array}{l}\text { Hypro GUARDIAN AIR } \\
\text { 120015 }\end{array}$ & Air induction single flat spray & Coarse & $341-403 \mu \mathrm{m}$ \\
Micron 110 DB 1,5 AIR & Air induction twin flat spray & Very coarse & $404-502 \mu \mathrm{m}$ \\
\hline
\end{tabular}

* ASABE/ANSI/ASAE Standard S572.1 (ASABE, 2013) ** Volumetric median diameter

It was used the systemic fungicide with active ingredient trifloxystrobin $\left(60 \mathrm{~g}\right.$ a.i. $\left.\mathrm{L}^{-1}\right)+$ prothioconazole $\left(70 \mathrm{~g}\right.$ a.i. $\left.\mathrm{L}^{-1}\right)$, commercial name $\mathrm{Fox}^{\circledR}$, with the addition of an adjuvant composed of methylated ester of soybean oil $\left(270 \mathrm{~g}\right.$ a.i. $\left.\mathrm{L}^{-1}\right)$, commercial name Áureo ${ }^{\circledR}$. In each one of the applications, the dose of the fungicide was $0.40 \mathrm{~L}$ of commercial product $\mathrm{ha}^{-1}$ and the adjuvant $0.25 \mathrm{~L} \mathrm{ha}^{-1}$.

The necessity and the number of fungicide applications were determined according to the presence of the disease in the area, residual effect of the product and favorable meteorological conditions for the development of the disease. Four fungicide applications were necessary at intervals between applications of approximately 14 days.

During the fungicide applications, readings and recording of the air conditions were carried out, using a thermo-hygro-anemometer, Kestrel ${ }^{\circledR} 3000$ brand. The air conditions at the time of application of fungicides were favorable (Table 2).

The first application was performed at the vegetative stage, when the first symptoms of the disease were confirmed in the lower canopy, that is, with an incidence of approximately $3 \%$. At the moment, there was no closure between the rows of the crop. In the second, third and fourth application of fungicide, the closure of the inter rows of the soybeans was total; the rust was present in the lower and upper canopy. 
TABLE 2. Air conditions observed during the applications carried out for the control of Asian soybean rust, 2013/2014 harvest. Água Santa, RS.

\begin{tabular}{|c|c|c|c|c|c|}
\hline \multicolumn{6}{|c|}{ 2013/2014 HARVEST } \\
\hline Applications/Dates & DS & Time & Temp. $\left({ }^{0} \mathrm{C}\right)$ & R.H (\%) & W.S $\left(\mathrm{km} \mathrm{h}^{-1}\right)$ \\
\hline $02 / 17 / 2014$ & V7 & $10: 00$ & 28 & 53 & 6.0 \\
\hline Second $03 / 14 / 2014$ & R3 & $10: 00$ & 26 & 55 & 6.5 \\
\hline Third $\quad 25 / 03 / 2014$ & R5.5 & $17: 00$ & 19 & 58 & 7.0 \\
\hline Fourth $04 / 12 / 2014$ & R7.1 & $17: 30$ & 20 & 58 & 7.3 \\
\hline
\end{tabular}

DS - Development stage of the soybean plant based on the Yorinori (1996) scale. Temp. - Air temperature R.H - Air relative humidity. W.S - Wind speed.

The fungicide applications were carried out with a backpack sprayer with constant pressure $\left(\mathrm{CO}_{2}\right)$, equipped with a $2.0 \mathrm{~m}$ bar, with four nozzles spaced $0.5 \mathrm{~m}$ apart, conducted at a height of 0.5 $\mathrm{m}$ above the plants apex. The working pressure was $300 \mathrm{kPa}$, for all spray nozzles compared. The application rate in all treatments was calibrated to $150 \mathrm{~L} \mathrm{ha}^{-1}$ and displacement velocity of $1.31 \mathrm{~m}$ $\mathrm{s}^{1}$.

The evaluation of rust severity was carried out at intervals of approximately seven days, totalizing seven evaluations. The first severity evaluation was performed 54 days after the emergency (DAE). For this, four plants per plot were collected, located in the useful area of the experimental plot, highlighting all leaflets, separating in upper canopy and lower canopy of soybean crop.

All sampled leaflets were randomly marked with four $1.0 \mathrm{~cm}^{-2}$ points, to obtain the mean number of uredinia $\mathrm{cm}^{-2}$, observed with the aid of a stereoscopic microscope. The sum of the number of uredinia $\mathrm{cm}^{-2}$ of all sick leaves was divided by the total number of leaflets of the sample, and it was considered to be the leaf severity of the plot, expressed in uredinia $\mathrm{cm}^{-2}$.

The uredinia $\mathrm{cm}^{-2}$ values allowed to integrate the area under the disease progress curve (AUDPC). This was calculated by the sum of the trapezoidal areas, according to the methodology proposed by Campbell \& Madden (1990).

The harvest was carried out on 05/03/2014, manually harvesting the three central lines by five meters in length, totalizing a useful area of $6.75 \mathrm{~m}^{2}$ in each plot. The grain yield was determined after cutting and tread, in stationary motorized treadmill. The harvested grains per plot were weighed in a digital scale, with an accuracy of five grams and the humidity was determined in a moisture meter, correcting for the water content of $13 \%$ (h.b.), being used to calculate the yield.

The data were submitted to analysis of variance $(\mathrm{p}<0.05)$ and the averages compared by the Tukey test at $5 \%$ error probability, trough the $\mathrm{SAS}^{\circledR}$ program.

\section{RESULTS AND DISCUSSION}

Table 3 shows the comparison between the treatments that received fungicide and the control, regarding AUDPC and grain yield in response to the application of the fungicide with different spray nozzles. 
TABLE 3. Area under the disease progress curve (AUDPC) of Asian Soybean Rust in the upper canopy, lower canopy and the whole plant, due to different spray nozzles used in applications of trifloxystrobin + prothioconazole fungicide. 2013/2014 harvest. Água Santa, RS.

\begin{tabular}{lccc}
\hline \multirow{2}{*}{ Nozzles - Models } & \multicolumn{3}{c}{ AUDPC } \\
\cline { 2 - 4 } & \multicolumn{3}{c}{ Phakopsora pachyrhizi } \\
\cline { 2 - 4 } Jacto JA-2 & $2.472 \mathrm{~d}$ & $3.751 \mathrm{~b}$ & $6.223 \mathrm{bcd}$ \\
Micron 110 DB 1,5 & $2.806 \mathrm{bcd}$ & $3.209 \mathrm{bc}$ & $6.015 \mathrm{bcd}$ \\
Teejet DGTJ- 60 110015 & $2.549 \mathrm{~cd}$ & $2.228 \mathrm{cde}$ & $4.776 \mathrm{de}$ \\
Teejet XR110015 & $2.825 \mathrm{bcd}$ & $2.962 \mathrm{bcd}$ & $5.787 \mathrm{bcd}$ \\
Magno 110015-BD & $3.256 \mathrm{bc}$ & $1.749 \mathrm{de}$ & $5.006 \mathrm{cde}$ \\
Teejet TT 110015 & $2.645 \mathrm{bcd}$ & $3.479 \mathrm{bc}$ & $6.124 \mathrm{bcd}$ \\
Hypro GUARDIAN 120015 & $2.314 \mathrm{~d}$ & $1.302 \mathrm{e}$ & $3.615 \mathrm{e}$ \\
Agrotop AIRMIX 110015 & $2.989 \mathrm{bcd}$ & $2.199 \mathrm{cde}$ & $5.189 \mathrm{bcde}$ \\
Hypro GUARDIAN AIR 120015 & $3.010 \mathrm{bcd}$ & $3.528 \mathrm{~b}$ & $6.538 \mathrm{bc}$ \\
Micron 110 DB 1,5 AIR & $3.398 \mathrm{~b}$ & $3.468 \mathrm{bc}$ & $6.866 \mathrm{~b}$ \\
Control & $11.139 \mathrm{a}$ & $11.242 \mathrm{a}$ & $22.381 \mathrm{a}$ \\
\hline \multicolumn{1}{c}{ CV (\%) } & 7.4 & 12.2 & 8.3 \\
\hline
\end{tabular}

Area under the disease progress curve (AUDPC) based on severity (uredinia $\mathrm{cm}^{-2}$ ).

Averages followed by the same letter in column do not differ from each other by Tukey test at $5 \%$ probability.

In all treatments with fungicide application, both the upper canopy and the lower canopy of the AUDPC of Asian soybean rust showed lower values when compared to the control. Therefore, the data showed in Table 3 allow verifying the efficiency of the fungicide in the control of rust in the evaluated conditions.

The Hypro GUARDIAN 120015 single pre-orifice flat spray nozzle shows the lowest AUDPC value of rust in the lower canopy and, considering the canopy of the entire soybean crop, shows the smallest amount of uredinia $\mathrm{cm}^{-2}$. However, the same does not differ significantly from the Teejet DGTJ-60 110015 twin pre-orifice flat spray, Magno 110015-BD and Agrotop AIRMIX 110015 single spray tips.

In the case of soybean rust having its initial development in the lower region of the soybean crop, the Hypro GUARDIAN 120015 single pre-orifice spray nozzle, which produces a medium droplet spectrum, proved to be efficient for the control of the pathogen, when the lower canopy and entire plant were analyzed.

In the upper canopy, the Hypro GUARDIAN 120015 single pre-orifice flat jet nozzle showed the lowest AUDPC value, but there was no significant difference in relation to the other evaluated nozzles, except Magno 110015 BD and Micron 110 DB 1.5 AIR.

It is believed that spray nozzles, which produced very fine, coarse and very coarse droplets categories, had difficulty in depositing an adequate amount of fungicide on the target and consequently provided less control of soybean rust. The nozzles that showed characteristics of coarse and very coarse droplets could not promote the transposition of the barriers imposed by the leaves due to the shading between the soybean rows at the moment of application of the fungicide. On the other hand, the droplets generated by spray nozzles that generate very fine spectra (twin flat fan jet), besides these difficulties, are also more vulnerable to drift loss and evaporation.

Therefore, when using nozzles that produce spectra of droplets with characteristics of very fine, fine, coarse and very coarse, the highest values of AUDPC of soybean rust were generally obtained.

This is believed to be due to the fact that fine droplets have a very reduced life expectancy, while the medium droplets suffer less risk of drift and evaporation (Cunha et al., 2014). On the 
other hand, the air induction twin flat spray nozzles, because they produced larger droplets, can be one of the alternatives adopted to reduce the intensity of the drift phenomenon (Bueno et al., 2013).

In addition, the energy loss (velocity) of the fine droplets influences in the lower canopy deposition of the soybean crop. In the application of systemic fungicide, the pulverized spray solution must remain in contact with the leaf for a minimum period, so that the plant can absorb the active ingredient, according to $\mathrm{Yu}$ et al. (2009). In this sense, the active ingredient needs to be placed in the target under the risk of not controlling the disease (Tormen et al., 2012). Therefore, it is possible to emphasize that the spray nozzles that contributed to the lower AUDPC of the soybean rust and for greater safety in the application in relation to the other spray nozzles used were the Hypro GUARDIAN 120015 single pre-orifice flat spray, showing medium drop characteristics.

The data obtained in this study are in accordance with reports by Cunha et al. (2014), who verified, after eight years of study, that spray nozzles that produce medium drops showed better results of deposition and soybean rust control.

Table 4 shows the grain yield obtained according to the different compared spray nozzles models. The productivity was higher than the control in all the treatments that received the fungicide applications, and no significant differences were found between the compared spray nozzles models.

TABLE 4. Grain yield in response to trifloxystrobin + prothioconazole fungicide applications with different spray nozzles for the 2013/2014 harvest. Água Santa, RS.

\begin{tabular}{lc}
\hline Spray Nozzles - Models & Yield $\left(\mathrm{kg} \mathrm{ha}^{-1}\right)$ \\
\hline Jacto JA-2 & $2.206 \mathrm{a}$ \\
Micron 110 DB 1,5 & $2.553 \mathrm{a}$ \\
Teejet DGTJ- 60 110015 & $2.359 \mathrm{a}$ \\
Teejet XR110015 & $2.347 \mathrm{a}$ \\
Magno 110015-BD & $2.250 \mathrm{a}$ \\
Teejet TT 110015 & $2.492 \mathrm{a}$ \\
Hypro GUARDIAN 120015 & $2.584 \mathrm{a}$ \\
Agrotop AIRMIX 110015 & $2.369 \mathrm{a}$ \\
Hypro GUARDIAN AIR 120015 & $2.600 \mathrm{a}$ \\
Micron 110 DB 1.5 AIR & $2.268 \mathrm{a}$ \\
Control & $880 \mathrm{~b}$ \\
\hline CV $(\%)$ & 12.35 \\
\hline
\end{tabular}

Averages followed by the same letter in column do not differ from each other by Tukey test at $5 \%$ probability.

The treatments with the fungicide allowed an average productivity of $288 \%$ higher than that obtained in the control. The low yield of $880 \mathrm{~kg} \mathrm{ha}^{-1}$ obtained in the control was probably due to the premature fall of the soybean leaves, due to the severe attack of the soybean rust that occurred in the referred agricultural year, as well as the (late) sowing season that was carried out in nonpreferential period.

Data presented by Cunha et al. (2011) showed productivity $224 \%$ higher than the control, indicating that the productivity was also not influenced by the use of different spray nozzles in fungicide applications.

Observing Table 4, the productivity of the soybean crop was not influenced by the use of the different models of spray nozzles. The reason that there was no significant difference in grain yield between the spray nozzles models can be attributed to the fact that, even though the difference between the AUDPC in the different canopies by the different nozzles was significant, they were insufficient to differentiate the productivity of the plants. However, the chemical treatment showed satisfactory control of soybean rust. 
The lack of productivity difference in relation to the different spray nozzles models can also be attributed to the chemical management used, tolerance or partial resistance of the cultivar, aggressiveness and occurrence of the pathogen in the area. Similarly, Nascimento et al. (2013) also did not obtain significant difference between different spray nozzles in the production of grains between the plots treated with fungicide.

\section{CONCLUSIONS}

Treatments that received fungicide applications do not show differences between spray nozzles (hollow cone, twin flat, pre-orifice twin flat, flat, pre-orifice flat, single turbulence chamber flat, air induction single flat and air induction twin flat) as well as the productivity of the soybean crop.

The trifloxystrobin + prothioconazole fungicide reduces the severity of rust, which reflects in productivity, on average, $288 \%$ higher than that obtained in the control.

The severity of Asian rust varies according to the spray nozzle models. The applications with Hypro GUARDIAN 120015 single pre-orifice flat nozzle, which generates medium droplet spectrum, provided the lowest AUDPC values of rust in the lower and upper canopy of soybean crop.

\section{REFERENCES}

ASABE (American Society of Agricultural and Biological Engineers). Spray Nozzle Classification by Droplet Spectra. ASABE/ANSI/ASAE S572.1 W/Corr. St. Joseph, Ml 49085-9659, USA, 1. MAR2009 (R2013)

Beledelli D, Neto DC, Cassettari LS, Machado AQ (2012) Viabilidade de urediniósporos de Phakopsora pachyrhizi Sidow na ausência do hospedeiro. Bioscience Journal 28(4):604-612.

Bueno MR, Cunha JPAR, Roman RAA (2013) Tamanho de gotas de pontas de pulverização em diferentes condições operacionais por meio da técnica de difração do raio laser. Engenharia Agrícola 34(5):976-985.

Boller W, Ferreira MC, Costa DI (2011) Condições do ar e angulação das folhas influenciam a qualidade das pulverizações na cultura da soja? Revista Plantio Direto (121):33-37.

Campbell CL, Madden LV (1990) Introduction to plant disease epidemiology. New York, J. Wiley \& Sons.

CONAB - Companhia Nacional De Abastecimento. Acompanhamento da safra brasileira de grãos. (2013) CONAB Available:

http://www.conab.gov.br/OlalaCMS/uploads/arquivos/16_01_12_14_17_16_boletim_graos_janeiro _2016.pdf. Accessed: Jan 28, 2016.

Constantin J, Sales JGC, Maciel CDG (2012) Característica da deposição e distribuição da calda de pulverização na cultura da soja em estádio fenológico V6. Engenharia Agrícola 32(3):530-541.

Cunha JPARda, Farnese AC, Olivet JJ, Villalba J (2011) Deposição de calda pulverizada na cultura da soja promovida pela aplicação aérea e terrestre. Engenharia Agrícola 31(2):343-351.

Cunha JPAR, Juliatti FC, Reis EF (2014) Tecnologia de aplicação de fungicida no controle da ferrugem Asiática da soja: resultados de oito anos de estudo em Minas Gerais e Goiás. Bioscience Journal 30(4):950-957.

Dorrance AE, Lipps PE, Mills D, Sánchés MV (2011) Soybean rust. Ohio State University. Available: http://ohioline.osu.edu/ac-fact/0048.html. Accessed: Dec 18, 2015.

Godoy CV, Utiamada CM, Meyer MC, Campos HD, Roese AD, Forcelini CA (2012) Eficiência de fungicidas para o controle da ferrugem-asiática da soja, Phakopsora pachyrhizi, na safra 2011/12: resultados sumarizados dos ensaios cooperativos. Londrina, Embrapa Soja. 8p (Circular Técnico, 93). 
Nascimento JM, Gavassoni WL, Souza CMA, Bacchi LMA, Serra AP, Zaccaron ML (2013)

Pontas de pulverização e horários de aplicação no controle químico de ferrugem asiática da soja. Ciências Agrárias 34(5):2037-2048.

Neves JSda, Blum LEB (2014) Influência de fungicidas e fosfito de potássio no controle da ferrugem asiática e na produtividade da soja. Revista Caatinga 27(1):75-82.

Souza DF (2013) Soja crua em dietas extrusadas para gatos. Dissertação Mestrado, Universidade Estadual Paulista, Faculdade de Ciências Agrárias e Veterinárias.

Streck EV, Kämpf N, Dalmolin RSD, Klamt E, Nascimento PC, Schneider P, Giasson E, Pinto LFS (2008) Solos do Rio Grande do Sul. EMATER/RS-ASCAR, 2 ed. 222p.

Tormen NR, Silva FDL, Debortoli MP, Uebel JD, Fávera DD, Balardin R (2012) Deposição de gotas no dossel e controle químico de Phakopsora pachyrhizi na soja. Revista Brasileira de Engenharia Agrícola e Ambiental 16(7):802-808.

Weirich PHW, Fornari AJ, Bauer FC, Justino A, Garcia LC (2013) Aplicação de fungicidas em soja com barra de arrasto. Engenharia Agrícola 33(4):876-882.

Yorinori JT (1996) Cancro da haste da soja: epidemiologia e controle. Londrina, Embrapa-Soja, 75p. (Circular Técnico, 14).

Yu Y, Zhu H, Ozkan HE, Derksen RC, Krause CR (2009) Evaporation and deposition coverage area of droplets containing insecticides and spray additives on hydrophilic, hydrophobic, and crabapple leaf surfaces. Transactions of the ASAE 52:39-49. 